\title{
Correlation of Total Cholesterol and Protein in Urine in Patients with the NEPHROTIC Syndrome
}

\author{
D. Jüngst, J. Wallner, and H.J. Karl \\ Medizinische Klinik 2 (Direktor: Prof. Dr. G. Paumgartner) Klinikum Großhadern der Universität München
}

Korrelation von Cholesterin und Protein im Urin

bei Patienten mit nephrotischem Syndrom

Zusammenfassung. Bei 42 Patienten mit nephrotischem Syndrom wurde die Protein- und Cholesterinausscheidung im 24 Stundenurin gemessen. Die gefundene positive Korrelation $(r=0,76, p<0,01)$ zwischen Cholesterin und Protein im Urin wäre vereinbar mit einer gesteigerten glomerulären Filtration von Plasmalipoproteinen als Ursache der Lipidurie beim nephrotischen Syndrom.

Schliusselwörter: Nephrotisches Syndrom - Gesamtcholesterin im Urin - Protein im Urin

Summary. The excretion of protein and cholesterol in $24 \mathrm{~h}$ urine was measured in 42 patients with the nephrotic syndrome. The finding of a positive correlation $(r=0.76, p<0.01)$ between urinary cholesterol and urinary protein would be compatible with an enhanced glomerular filtration of plasma lipoproteins as the cause of lipiduria in the nephrotic syndrome.

Key words: Nephrotic syndrome - Urinary total cholesterol - Urinary protein

Lipiduria is a commonly emphasized component of the nephrotic syndrome and refers usually to the birefringent or anisotropic crystals found in the urinary sediment of these patients. These anisotropic bodies have the typical "Maltese cross" appearance when viewed with a polarizing microscope and cholesterol esters have been identified as the major components of these elements [6, $8,9]$.

A positive correlation between urinary cholesterol and urinary protein has been reported in several studies $[1,6]$ but could not be confirmed by others [2]. Most authors agree that an increased glomerular permeability to lipoprotein is probably necessary before appreciable amounts of lipid appear in the urine $[1-3,5-9]$.

However, in all the said former studies urinary cholesterol was determined using nonspecific analytical procedures, mainly colorimetric methods.

Therefore, we studied with a specific gasliquid chromatographic method, whether a positive correlation would exist between urinary protein and urinary cholesterol in patients with the nephrotic syndrome.

Offprint requests to: Dr. D. Jüngst (address see page 1216)
A nephrotic syndrome was defined as a clinical state in which there is a combination of oedema, proteinuria and hypoproteinaemia, irrespective of the aetiology or any other clinical features. This definition stresses the occasional clinical similarities of many unrelated diseases.

Total urinary cholesterol was analyzed in $2 \mathrm{ml}$ aliquots of $24 \mathrm{~h}$ urine. After extraction with $6 \mathrm{ml}$ ethyl acetate for 30 min in a rotating system, the urinary phase was removed. The ethyl acetate extract was purified with alkali $(2 \mathrm{ml} 0.1 \mathrm{~N} \mathrm{NaOH})$ and water washings and dried under a stream of nitrogen. The residue was dissolved in $0.1 \mathrm{ml}$ of the internal standard solution $(10 \mathrm{mg}$ 4-androstene-3,17-dione/dl isooctane), followed by GLC on a $180 \mathrm{~cm} 1 \%$ XE 60 column, i.d. $2 \mathrm{~mm}$, temperature const. $220^{\circ} \mathrm{C}$. Quantitation was performed due to the peak height ratio, since alterations of cholesterol and 4androstenedione concentrations gave a linear response. For the determination of total urinary cholesterol hydrolysis of the dried extract with $0.1 \mathrm{ml} 3 \mathrm{~N} \mathrm{KOH}$ and $0.9 \mathrm{ml}$ ethanol for $60 \mathrm{~min}$ at $60^{\circ} \mathrm{C}$ was necessary prior to GLC [4]. The specificity of the method was confirmed by simultaneous mass-fragmentometric analysis in selected samples ${ }^{+}$.

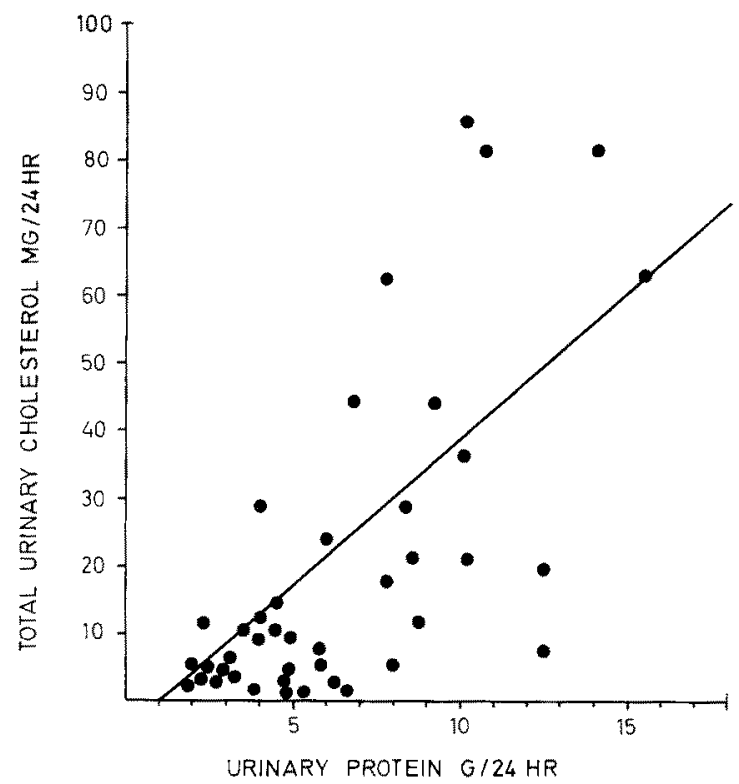

Fig. 1. Correlation of total urinary cholesterol and urinary protein in patients with the nephrotic syndrome $(r=0.76, p<0.01)$ 
The study included a total of 42 patients, 17 males and 25 females, ranging in age from 18 to 72 years.

The correlation of urinary total cholesterol and urinary protein is illustrated in Fig. $1(r=0.76, p<0.01)$.

In the present study the positive correlation between urinary protein and urinary cholesterol in patients with the nephrotic syndrome, which had been reported [6] recently, could be confirmed using specific GLC. These findings seem to support the suggestions of some authors [7] that plasma lipoproteins are responsible for lipiduria in patients with the nephrotic syndrome.

Acknowledgements: Massfragmentometric analysis were kindly provided by PD Dr. Jacob, Institut für Klinische Chemie im Klinikum Großhadern (Direktor: Prof. Dr. Knedel) der LMU München, Marchioninistr. 15,8000 München 70.

\section{References}

1 Bruger M (1935) Cholesteroluria in Bright's disease. Am J Clin Pathol 5:504-515

2 Comings DE (1963) Anisotropic lipids and urinary cholesterol excretion. JAMA 183:128-133

3 Gardner JA, Gainsborough H (1925) Cholesterol secretion in the urine. Part I. Biochem J 19:667-671

4 Jüngst D, Pickel A, Marx FJ, Elsässer E, Karl HJ (1979) Urinary cholesterol excretion in men with benign prostatic hyperplasia and carcinoma of the prostate. Cancer 43:353-359

5 Kayser F, Balat R (1952) Sur la présence et sur l'origine du cholestérol dans l'urine. Bull Soc Chim Biol 34:806-812

6 Klahr S, Tripathy K, Bolanos O (1967) Qualitative and quantitative analysis of urinary lipids in the nephrotic syndrome. $\mathrm{J}$ Clin Invest 16:1475-1481

7 Mendoza SG de, Kashyap ML, Chen CY, Lutmer RF (1976) High-density lipoproteinuria in nephrotic syndrome. Metabolism 25:1143-1149

8 Neuman M, West M, Zimmermann H (1961) The relationship between proteinuria and fatty elements in the urine sediment. Am J Med Sci 241:617-624

9 Zimmer JG, Dewey P, Waterhouse C, Terry R (1961) The origin and nature of anisotropic urinary lipids in the nephrotic syndrome. Ann Intern Med 54:205-214

Received January 29, 1980

Accepted July 8, 1980

Dr. D. Jüngst

Med. Klinik II

Klinikum Großhadern

Marchioninistr. 15

D-8000 München 70

Federal Republic of Germany

Verantwortlich für den Textteil : Prof. Dr. Herbert Schwiegk und Prof. Dr. Hans Jahrmärker, Medizinische Klinik (Innenstadt) der Universität, Ziemssenstraße 1, D-8000 München 2; für den Anzeigenteil: L. Siegel, E. Lückermann, Springer-Verlag KG, Kurfürstendamm 237, D-1000 Berlin 15. - Springer-Venlag, Berlin Heidelberg New York und J.F. Bergnann-Velag, München. - Druck der Universitätsdruckerei $H$. Stürtz $A G$, Würburg.

Printed in Germany. - C Springer-Verlag, Berlin. Heidelberg 1980 